\title{
GRAMMATICAL ERRORS ON STUDENTS' WRITING OF RECOUNT TEXT
}

\author{
Natalia Widya Pasca Tarigan ${ }^{1}$ \\ Universitas Prima Indonesia \\ Yudha Suranta P. Siregar ${ }^{2}$ \\ Universitas Prima Indonesia \\ Cindy Ika Mawarni ${ }^{3}$ \\ Universitas Prima Indonesia \\ Christine Widyantari Br. Simanjuntak ${ }^{4}$ \\ Universitas Prima Indonesia \\ Alfian Tanjaya $^{\mathbf{5}}$
Universitas Prima Indonesia
yudhasurantaa@gmail.com ${ }^{2}$
}

Submit, 29-11-2019 Accepted, 29-12-2019 Publish, 29-12-2019

\begin{abstract}
This research aims to classify and analyze students' types and sources of errors in writing recount text using simple past tense. This research used descriptive qualitative research. Furthermore, researchers used a written test and chose the 2nd grade students of Senior High School and observed 20 students. It was found the students do all the types of errors. Selection errors was the most common types of errors with 94 or $44,98 \%$ of errors. The second was the omission errors with 56 or $26,79 \%$ of errors. The third was the addition errors with 43 or $20,57 \%$ of errors. Then the last was misordering errors with 16 or $07,66 \%$ of errors. Furthermore, the errors weren't caused by Indonesian language's system but the complexity of English language's system. Moreover, the lack of students' understandings of grammar was the cause of the errors. In this research, most of the students didn't understand present and past form of the verbs. It can be concluded that students had difficulty in writing using properly grammar because the English language's system.
\end{abstract}

Keywords: error analysis, types of errors, sources of errors. 


\section{INTRODUCTION}

Language has a central role in human life as a means that communication used by human beings to communicate with each other. People use language as a medium to speak to others and express their ideas, opinions, wishes and also feelings. By using language, people are able to interact with each other and maintaining relations with them. Harmer (2007) states that "Language is used widely for communication between people who do not share the same first language (L1) or even second language (L2)." That's one of the reasons why people should master one of the languages in order that we can speak and understand what we are talking about. Learning a foreign language (FL) is really different from learning our mother tongue. The foreign language (FL) we are talking about in here is English. English is very important and becomes an international language which is spoken by many people around the world as the L1 or as a L2. Crystal (2003) states that "english is the medium of a great deal of the world's knowledge, especially in such areas as science and technology. Because of this importance, English is becoming a subject to be learned in every school and every university in Indonesia." In learning English, there are four main skills which the students should acquire, namely speaking, listening, writing, and reading. These skills are relates one to another. As Harmer (1989) explains that "listening and reading skills that involve receiving messages are regarded as receptive skills. While speaking and writing skills which involve language production are considered to be productive skills." Besides the four English skills, they should have the capability of grammar, vocabulary, and pronunciation. Those are called Language Component of English.

One of the important basic language skills that have to be mastered by students is writing, because with that skill students can compose a simple text by applying the English language. As productive skills, writing isn't like speaking skills or another receptive skill. Writing, which is one of the most complicated skills to be mastered, does not only need lots of vocabulary in arranging a paragraph, but also grammatically correct in order to be comprehensible besides other writing rules. Moreover, composing a paragraph in writing takes a lot of time. It is supported by Harmer (2004) statements that, "writing is often not timebound in the way conversation is. When writing, students frequently have more time to think than they do in oral activities. They can go through what they know in their minds, and even consult dictionaries, grammar books or other reference material to help them. Especially for the L2 learners or FL learners, the difficulty in writing doesn't only lie in organizing and creating ideas, but it also translating the ideas into readable writing." As Richards \& Renandya (2002) statement that, "There is no doubt that writing is the most difficult skill for L2 learners to master. The difficulty lies not only in generating and organizing ideas, but also in 
translating these ideas into readable text. The skills involved in writing are highly complex. L2 writers have to pay attention to higher-level skills of planning and organizing as well as the lower level skill of spelling, punctuation, word choice, and so on." Indonesian writing is not much different with English. However, English language's grammar structures are different from Indonesian language's grammar structures. Indonesian hasn't specific grammatical forms to indicate the time like English language. It can be measured that the written products as the students' achievement in the process of learning the language. That is why writing skills become an important part of the students' English learning process.

Researchers reviewed some previous research to find out what have been studied by another researcher which can be used as references to conduct the better study. The first research was conducted by Istibsyaroh (2014) shows that the data were collected by using Corder's theory to find the types of errors and Betty Azar to find the classification of errors. Second research was written by Millah (2016) tells that the writer used Betty Azar's theory to find the types of errors and Richard's sources of errors. Last research was written by Tarigan (2019) tells that the data only used Surface Strategy Taxonomy to find the types of the errors in narrative text. Meanwhile, in this research the researchers used Dulay's Surface Strategy Taxonomy to find the types of error and Brown's method (Interlingual and Intralingual transfer) to find the sources/causes of the errors. Because it is more relevant and easier for researchers also teachers to find the types of grammatical errors on students' writing of recount text and what is the sources of the errors.

\section{LITERATURE REVIEW}

The study of error is called error analysis. It is a way of looking at the errors made by the students in the process of learning the target language. It could be because of students' partial learning when the learning process, whether it from students fatigue or carelessness or others. It is supported by Richard (2002) states that, "errors sometimes made by a learner when writing or speaking and which is caused by lack of attention, fatigue, carelessness, or some other aspect performance." That is why error analysis is useful to identify, to describe, and to explain the errors. It can help the teachers to minimize the students' errors in their learning, especially in their writing. Error analysis is adventegous for both teachers and also learners. For teachers, they will know wether they are succesful or not in teaching Englis. While for students, error analysis is needed to show them which aspect of grammar are difficult for them.

Error and mistake are not the same, it is crucial to make a distinction between them. Most people still misunderstand about the definition of both. Jeremy Harmer in Istibsyaroh (2014) said that "mistake" is "less" serious since it 
is the retrieval that is faulty not the knowledge. In other words, the students know the rules, but they make a "slip" when producing it. Meanwhile Douglas Brown gave different meanings, "A mistake refers to a performance error that is either a random guess or a slip." (Evayani, 2013). In that meaning, it is a failure to utilize a known system correctly. Because all people make mistakes in both native and L2 situations. From those points of view, it can be said that mistakes are the failure to use language because of the slip of the tongue or spelling and the learner can easily correct this failure. On the other hand, errors are mistakes that the students make due to lack of competence. They are not able to do self-correction because they do not know the concept. This is supported by James 1998 (Brown, 2007) that says, "The difference between an error and a mistake is that an error can not be corrected itself while mistake can be corrected by someone or themselves."

In analyzing how far students' ability in understanding grammar of language, it would be easy to analyze it through the surface strategy taxonomy. Dulay et al. (1982) classified the surface strategy taxonomy into four: 1) Error of Omission: "Omission errors are characterized by the absence of an item that must be appear in a well-formed utterance.", 2) Error of Addition: "Addition errors are the opposite of ommision errors. They are characterized by the presence of an item, which must not appear in a well-formed utterance.", 3) Error of Selection: "Misformation or Selection errors are characterized by the use of the wrong form of the structure or the morpheme." It's usually appeared because the students are wrong in choosing the properly or suitable words., 4) Error of Misordering: "Misordering errors are characterized by the incorrect placement of a morpheme or group of morphemes in an utterance."

Errors are usually happened because of some causes. The obvious causes is the interference from the native language, because students haven't mastered the L2. One of the strategies to prevent students or learners from making the same errors is by looking at sources of errors itself, is it from interlingual or intralingual. Brown (2007) classified the sources of errors into four categories: 1) Interlingual Transfer: "The beginning stages of learning a L2 are especially vulnerable to interlingual transfer from the native language or interference." It means Interlingual transfer is an error caused by the students' L1. It's caused by the changed of the L1 elements into L2. Because L1 is the only language used by the learners before the L2., 2) Intralingual Transfer: "Intralingual transfer contributes a large error than interlingual errors in L2." This error occured because the students' error in learning the L2 caused by the complexity of English language's system. 3) Context of Learning: "Context refers to the classroom with its teacher and materials in the case of school learning or the social situation in the 
case of untutored L2 learning.", 4) Communication Strategies: "Verbal or nonverbal mechanism for communicating the idea of using the right language."

\section{RESEARCH METHOD}

The research design used by the researchers in this research was conducted through descriptive qualitative research by using writing test and interview as the research instrument. The subjects of this research were the second - grade students of SMA Al - Asy' Ariyah Medan. The second - grade in this school consists of three classes, one class of XI IPA and two classes of XI IPS. Researchers only focused on the XI IPA class which consisted of 36 students. In collecting the data, researchers used writing test instruments to investigate students' grammatical errors. Researchers asked the students to write a recount text with a particular theme, namely "Unforgettable Holiday".

\section{FINDING}

The researchers did the test and interviews on $11^{\text {th }}$ November 2019. After the test, researchers did the interview to an English teacher and three students. It can be concluded that most of the students didn't understand writing recount text in simple past tense. They got confused to differentiate among the verb 1, 2, and 3. Moreover, they also can not differentiate between the regular and irregular verbs. Hence, student still needed help from dictionary to differentiate them. The most difficulty was to differentiate the verb one, two, and three in the irregular verbs. Because of it, students found difficulty in writing recount text. Furthermore, the English teacher taught the topic using the example sentence method. It was to provide examples for students and discuss it together, so students could understand the sentences pattern. Also, teacher stated the textbook could not really describe the materials in details. In addition, students often translated Indonesian word into English language word by word. Which they took from the Indonesian language's patterns.

After the researchers did the interview, researchers checked all the students' writing test. Only 20 students' writing met the researchers' requirement. Researchers marked and corrected all the errors. After that, researchers classified students' writing by types and sources of the errors. Then calculated the number of each error to get the percentage of each errors. Below was the result of the problem identification: 
Table 1 Recapitulation of Students' Error

\begin{tabular}{|c|c|c|c|c|c|}
\hline \multirow{2}{*}{ No. } & \multirow{2}{*}{ Students } & \multicolumn{4}{|c|}{ Types of Errors } \\
\hline & & Omission & Addition & Selection & Misordering \\
\hline 1 & $\mathrm{MF}$ & 2 & 2 & 4 & 0 \\
\hline 2 & SU & 7 & 5 & 15 & 4 \\
\hline 3 & $\mathrm{AK}$ & 7 & 7 & 22 & 0 \\
\hline 4 & $\mathrm{RP}$ & 2 & 5 & 7 & 2 \\
\hline 5 & HP & 1 & 3 & 5 & 1 \\
\hline 6 & VM & 9 & 2 & 0 & 0 \\
\hline 7 & ASS & 5 & 2 & 2 & 0 \\
\hline 8 & APR & 4 & 1 & 5 & 1 \\
\hline 9 & REK & 1 & 2 & 1 & 0 \\
\hline 10 & $\mathrm{BC}$ & 1 & 0 & 1 & 1 \\
\hline 11 & AP & 3 & 2 & 7 & 0 \\
\hline 12 & SB & 5 & 0 & 2 & 1 \\
\hline 13 & $\mathrm{AM}$ & 3 & 2 & 9 & 1 \\
\hline 14 & ARW & 0 & 1 & 0 & 0 \\
\hline 15 & $\mathrm{CA}$ & 1 & 1 & 2 & 2 \\
\hline 16 & NA & 1 & 2 & 2 & 1 \\
\hline 17 & MRH & 1 & 1 & 3 & 1 \\
\hline 18 & SRS & 0 & 3 & 3 & 0 \\
\hline 19 & $\mathrm{DP}$ & 2 & 0 & 2 & 0 \\
\hline 20 & NRA & 1 & 2 & 2 & 1 \\
\hline \multicolumn{2}{|c|}{ Total of Each Error } & 56 & 43 & 94 & 16 \\
\hline \multicolumn{2}{|c|}{ Total of All Errors } & \multicolumn{4}{|c|}{209} \\
\hline
\end{tabular}

The percentage of each types of errors:
1. The error of Omission
$=\frac{56}{209} \times 100 \%=26,79 \%$
2. The error of Addition
$=\frac{43}{209} \times 100 \%=20,57 \%$
3. The error of Selection
$=\frac{94}{209} \times 100 \%=44,98 \%$
4. The error of Misordering
$=\frac{16}{209} \times 100 \%=07,66 \%$ 
Table 2. Recapitulation The Types of Errors, Frequency \& Percentage

\begin{tabular}{clcc}
\hline No. & Types of Error & Frequency & Percentage \\
\hline 1 & Omission & 56 & $26,79 \%$ \\
\hline 2 & Addition & 43 & $20,57 \%$ \\
\hline 3 & Selection & 94 & $44,98 \%$ \\
\hline 4 & Misordering & 16 & $07,66 \%$ \\
\hline & Total & $\mathbf{2 0 9}$ & $100 \%$ \\
\hline
\end{tabular}

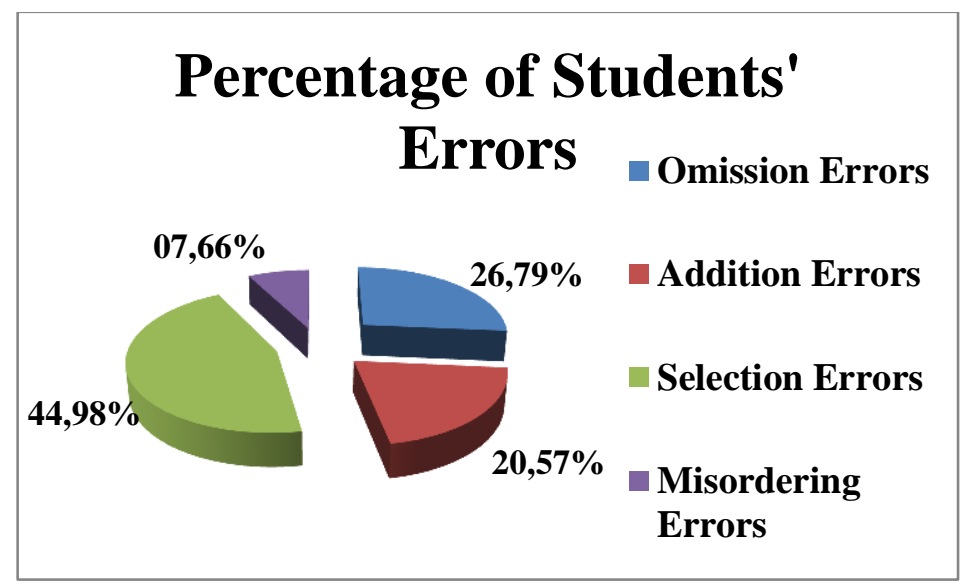

Chart 1 Percentage of Students' Errors.

\section{The Description of Error}

After identifying all the data, the researchers analyzed the errors and classified them based on Dulay et al. (1982) Surface Strategy Taxonomy to know the error of omission, error of addition, error of selection, and error of misordering.

\section{Omission Errors}

There were 56 or $26,79 \%$ total errors of omission. It is occurred because the students omitted an element that should exist in a sentence. The omission of that element might affect the meaning of the sentence.

Example : We stay until the sunset.

The correct sentence : We stayed until the sunset.

The example above has missing suffix -ed, so the word "stay" should be "stayed".

\section{Addition Errors}

There were 43 or $20,57 \%$ total errors of addition.

Example : We pay a visited three places. 
The correct sentence : We visited three places.

This error occured because the students added an item that shouldn't be in the sentence.

\section{Selection Errors}

There were 94 or $44,98 \%$ total errors of selection. It is occured because the students was wrong in choosing the right words for the sentence.

Example : The air is very cold.

The correct sentence : The air was very cold.

From the example, the student made an error in choosing the correct auxiliary verb "be". If we want to tell an events in the past, the auxiliary verb "is" should be "was".

\section{Misordering Errors}

There were 16 or $7,66 \%$ total errors of misordering. It is occured because the students made errors in arranging morpheme in sentences.
Example
: We many got lesson.

The correct sentence : We got many lesson.

From the example, there is an error of morphemes in composing the sentence, it will affect the understanding of the reader or the listener.

Table 3 Recapitulation of Students' Sources of Errors

\begin{tabular}{cccc}
\hline \multirow{2}{*}{ No } & \multirow{2}{*}{ Students } & \multicolumn{2}{c}{ Sources of Error } \\
\cline { 3 - 4 } & & Interlingua Transfer & Intralingua Transfer \\
\hline 1 & MF & 2 & 6 \\
\hline 2 & SU & 11 & 20 \\
\hline 3 & AK & 7 & 29 \\
\hline 4 & RP & 4 & 12 \\
\hline 5 & HP & 2 & 8 \\
\hline 6 & VM & 9 & 2 \\
\hline 7 & ASS & 5 & 4 \\
\hline 8 & APR & 5 & 6 \\
\hline 9 & REK & 1 & 3 \\
\hline 10 & BC & 2 & 1 \\
\hline 11 & AP & 3 & 2 \\
\hline 12 & SB & 6 & 11 \\
\hline 13 & AM & 4 & 3 \\
\hline 14 & ARW & 0 & \\
\hline 15 & CA & 3 & \\
\hline
\end{tabular}




\begin{tabular}{lccc}
16 & NA & 2 & 4 \\
\hline 17 & MRH & 2 & 4 \\
\hline 18 & SRS & 0 & 6 \\
\hline 19 & DP & 2 & 2 \\
\hline 20 & NRA & 2 & \\
\hline $\begin{array}{l}\text { Total of Each } \\
\text { Error }\end{array}$ & $\mathbf{7 2}$ & & $\mathbf{1 3 7}$ \\
\hline \begin{tabular}{l} 
Total All Errors \\
\hline
\end{tabular}
\end{tabular}

The percentage of each source of error was:
1. Interlingual transfer
$=\frac{72}{209} \times 100 \%=34.45 \%$
2. Intralingual transfer
$=\frac{137}{209} \times 100 \%=65.55 \%$

Table 4. Recapitulation The Sources of Errors, Frequency \& Percentage

\begin{tabular}{cccc}
\hline No. & Sources of Error & Frequency & Percentage \\
\hline 1 & Interlingua Transfer & 72 & $34,45 \%$ \\
\hline 2 & Intralingua Transfer & 137 & $65,55 \%$ \\
\hline Total & $\mathbf{2 0 9}$ & $\mathbf{1 0 0 \%}$ \\
\hline
\end{tabular}

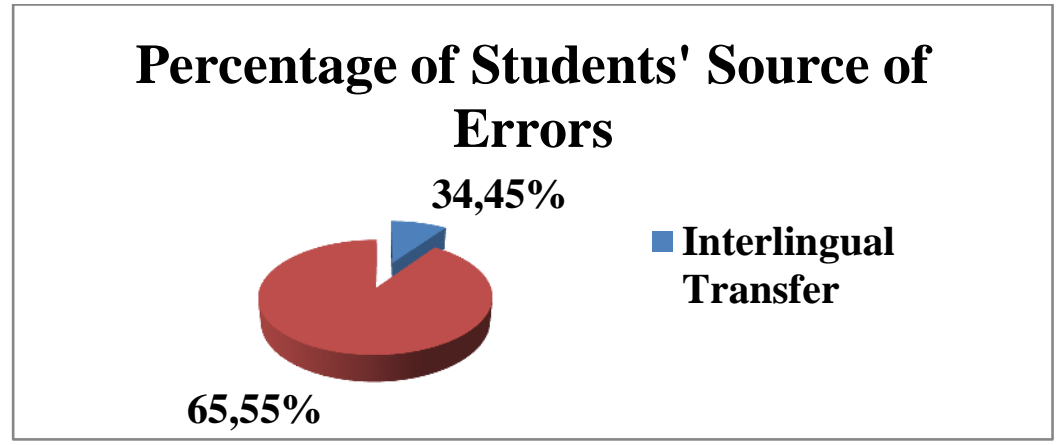

Chart 2. Percentage of Students' Source of Errors.

\section{The Explanation of Sources of Error}

The researchers classified the errors based on the source of the error. In this research, researchers analyzed the errors whether it came from Indonesian (Interlingual) or it came from English (Intralingual). The researchers only used Brown's sources of errors; intralingual transfer and interlingual transfer. 
Interlingual Transfer

Example : A moment that I can't forget.

Correct sentence : A moment that I couldn't forget.

In the example, the student still using the grammatical from the L1. The students do not change "can't" to "couldn't". That is because student don't use the grammatical of the second language (L2).

\section{Intralingual Transfer}

Example : My teacher's and friend's also look happy.

Correct Sentence : My teachers and friends also look happy.

From the example, the student want to tell that her teachers and her friends look happy. But, she put apostrophe that make the meaning different.

\section{DISCUSSION}

Based on the research finding, it could be concluded that the total of omission errors was 56 or $26,79 \%$ errors, addition errors was 43 or $20,57 \%$ errors, selection errors was 94 or 44,98\% errors, and misordering errors was 16 or $7,66 \%$ errors. From the data, selection errors was the most errors made by the students of SMA MAS Al Asy' Ariyah Medan with the percentage 44,98\% of errors. This is same like the result of Istibsyaroh (2014) research. This error occured because students choose the wrong word, they found difficulties in the use past tense. As stated by Dulay et al. (1982) "Misformation or Selection errors that are those characterized by the use of the wrong form of the morpheme or the structure." It suggested to students to learn more about past tense, because it can help the students in getting more complete understanding about the language elements being learnt. (Suhono, 2016). In the second position was followed by error of omission with the percentage $26,79 \%$ of errors. This error occured because the students omitted an element that should exist in a sentence and it might affect the meaning of the sentence. Next, third position was the addition errors with $20,57 \%$ of errors. It is because students put an item in their writing that shouldn't be in the sentence. And the last position was the error of misordering with the percentage $07,66 \%$ of errors.

For the sources of errors, intralingual was the major sources of errors made by the students with 137 or $65,55 \%$ errors. Meanwhile, the second position was interlingual made by the students with 72 or $34,55 \%$ errors. However, there were 4 students (student $6,7,10,12$ ) who made error in interlingual transfer. Furthermore, there were 14 students (student 1, 2, 3, 4, 5, 8, 9, 11, 13, 14, 16, 17, 18,20 ) who made error in intralingual transfer and only 2 students (students 15 , 19) who made error in both with the same number of frequencies. It is same by Brown (2007) statement about Intralingual Transfer, "Interlingual tranfer 
contributes a larger error compared to interlingual transfer in L2." It is because the L2 system or English language sytem is more difficult than Indonesian language system.

\section{CONCLUSION}

Based on this research, selection errors were the most types of errors made by the students in their writing recount text, because the students was wrong in choosing the right words. The second position was the omission errors, because the students omitted important items in the sentence. The third position was the addition errors, because students added an item that shouldn't be exist in the sentence. And the last position was the misordering errors, because students still following Indonesian language's system. From the data, it showed that the main source of errors was intralingual transfer. It is because the complexity of the English language's grammatical, not because the influence of Indonesian language system. The students' lacked of knowledge in understanding English grammar is the cause of the error. Students did not understand between verb one, two, three, as well as the properly use of "to be" in a sentence." In accordance with this research, this is some suggestion for the teacher and students (1) Teachers have to give feedback to students after correcting and analyze students writing's errors. (2) Teachers must teach the material in creative way, so students will be easy to understand. (3) Students should pay attention in learning writing. (4) Students should do more practice in their writing and do not be afraid in making mistake.

\section{REFERENCES}

Brown, H., D. (2007). Principle of Language Learning and Tecahing, 5th Edition. New York: Pearson Education, Inc.

Crystal, D. (2003). English as a global language (2nd ed.). Cambridge: Cambridge University.

Dulay, H., Burt, M., \& Krashen, S. (1982). Language Two. New York: Oxford University Press.

Evayani. (2013). An Analysis on Grammatical Errors in Students' Recount Text Writing (A Case Study at the Second Grade Students of MAN 10 Jakarta), UIN: Jakarta.

Harmer, J. (1989). The Practice of English Language Teaching. New York: Longman.

(2004). How to Teach Writing, Essex: Pearson Education Limited. (2007). How to Teach English. Harlow: Pearson Education Limited.

Istibsyaroh, A., D. (2014). Grammatical Errors on Students' Writing of Recount Text, UIN: Jakarta.

Millah, A. (2016) An Error Analysis on The Use Smple Past Tense in Students' Recount Text writting. (A Study at The Tenth Grade Of MA NU Banat Kudus), UIN: Walisongo. 
Richards, J., C \& Richard, S. (2002). Longman Dictionary of Language Teaching and Applied Linguistics, $3^{\text {rd }}$ Ed., London: Pearson Education Limited.

Richards, J., C \& Willy A., R. (2002). Methodology in Language Teaching: An Anthology of Current Practice, New York: Cambridge University Press.

Suhono. (2016). Surface Strategy Taxonomy on The EFL Students' Composition: A Study of Error Analysis. Iqra': Jurnal Kajian Ilmu Pendidikan.

Tarigan, K. (2019) An Analysis Of students' Grammatical Error in using Simple Past Tense in Writting Narrative Text at SMP Parulian 3 Medan., Universitas Prima Indonesia Medan. 